\title{
EFFECTS OF WATER MANAGEMENT ON HYDROLOGY AND WATER QUALITY OF A SEMI-ARID WATERSHED IN THE NORTHEAST OF BRAZIL
}

\author{
MOLISANI, M.M. ${ }^{1}$; LISIEUX, R. ${ }^{2}$; CAVALCANTE, M.D. ${ }^{2}$ \& MAIA, L.P. ${ }^{1}$ \\ ${ }^{1}$ Instituto de Ciências do Mar, Universidade Federal do Ceará, CEP: 60165-081, Fortaleza, CE, Brazil \\ Corresponding author: Te/FAX: +55 32421263, e-mail address: molisanimm@yahoo.com.br \\ ${ }^{2}$ Superintendência Estadual do Meio Ambiente do Estado do Ceará, CEP 60050-081 Fortaleza, CE, \\ Brazil
}

\begin{abstract}
Molisani, M.M.; Lisieux, R.; Cavalcante, M.D. \& Maia, L.P. 2007. Effects of water management on hydrology and water quality of a semi-arid watershed in the Northeast of Brazil. Braz. J. Aquat. Sci. Technol. 11(1):4349. ISSN 1808-7035. Water resource management based on dam construction, diversion, and other engineered hydraulic structures improves conditions for humans living in arid and semi-arid areas. However, the effects of damming on fluvial and coastal ecosystems are well-know, as it is the fact that economic and social development based on water management might enhance the pressure on such environments. This study gives a first basin scale representation of the possible effects of water resource management on hydrology and water quality of a typical semi-arid watershed/ estuarine system in Northeastern Brazil. Although the dam cascade suggests a hydrological alteration of the stream flow, the upstream location of dams in the Cocó watershed does not apparently alter the total discharge to the estuary. Water quality threats, such as high fecal coliform levels and low dissolved oxygen indicated that although water management supported extensive economic and social development, it resulted in considerable degradation of aquatic systems if no attention was paid to environmental and sanitary conditions.
\end{abstract}

Keywords: river, water quality, discharge, dam, estuary, Brazil

\section{INTRODUCTION}

Hydrology and water quality are important factors which have affected water resources in semi-arid areas (Al-Kharabsheh, 1999; Chellapa and Costa, 2003; Güntner et al., 2004). To increase water availability in order to meet the demands, semi-arid rivers have been intensively dammed and the negative impact that river regulations have on aquatic systems, including coastal areas, has been revealed (WCD, 2000). Dams in semiarid areas primarily serve as a water supply, which entails reducing the intensity and frequency of peak flows and increasing the importance of low flow conditions (Maingi and Marsh, 2002; Batalla et al., 2004; Singer, 2007). Additionally, hydrological changes imposed by dams can alter the land-sea transport of water, sediments and nutrients, which have modified the structure of many coastal ecosystems around the world (Cociasu et al., 1996; Harashima et al., 2006; Gong et al., 2006; Molisani et al., 2006a, 2007) and almost certainly, coastal areas adjacent to highly dammed semi-arid watersheds.

An additional factor driving the increasing water storage behind dams, and consequently water management, relates to the improvement of conditions for human settlement in semi-arid areas with considerable constraints for human subsistence. Water is a key restricting factor for socio-economic development, and as water availability has increased in semi-arid areas, based on water resource management, activities such as agriculture, industry and urbanization may experience growth. However, in the absence of sewage treatment plants, the amount of water used per inhabitant may return to the aquatic environments in improper sanitary conditions and deterioration of water quality has become a critical issue.

The actual number of drainage basins so far studied in the semi-arid Northeast of Brazil is reduced, and so more information is required for this region where the scarcity of water resources is the main constraint (Gaiser et al., 2003). In Ceará State, which is located in this region, watersheds are under the influence of a semi-arid climate and pronounced time and space variability of rainfall as well as recurrent droughts, which have affected the region. As a result, water is stored in reservoirs as much as possible (Campos and Studart, 2006). At this time, many areas are undergoing considerable socio-economic development based on water resource management such as dam construction and diversion, and consequently environmental threats on river and coastal systems have frequently been addressed, including poor water quality (Vieira et al., 1994, 2002; Moreira, 1994; Marins et al., 2002; Molisani et al., $2006 \mathrm{~b}$ ) and probably more subtle effects caused by damming. 
In this study, the effects of water resource management were analyzed in terms of hydrology and water quality of the Cocó River which is located in Ceará State and supplies water for a city with two-million inhabitants through a dam cascade-diversion scheme, suggesting important changes in this semi-arid river/ estuarine system.

\section{MATERIALS AND METHODS}

\section{Study area}

This study was carried out in the Cocó River watershed located in Ceará State, Northeast Brazil (Fig. 1). This region has recurrently been affected by intense drought, which has caused serious economic loss and social impact. Mean annual precipitation is about 850 $\mathrm{mm}$ with virtually all of the annual precipitation occurring between January and May. The inter-annual rainfall variability is high, with an annual rainfall variable coefficient of 0.36 . Potential evaporation amounts to about 2,100 mm (Gaiser et al., 2003).

The Cocó River watershed has an area of 360 $\mathrm{km}^{2}$ and is situated within a city of over two million inhabitants. To supply water for a variety of purposes (i.e., drinking, industry, agriculture, and recreation), about 30 dams were built across the watershed, ranging from small to the largest dam "açude", the Gavião reservoir with a storage volume of $29 \mathrm{hm}^{3}$ (Fig. 1). The dam cascade also receives water from an adjacent basin through a water diversion scheme. The Cocó River flows into the Atlantic Ocean at $3^{\circ} \mathrm{S}$ and $4^{\circ} \mathrm{S}$ latitude, and the flow and mixing within the estuary are mostly controlled by freshwater inflow and tide. The dominant feature of

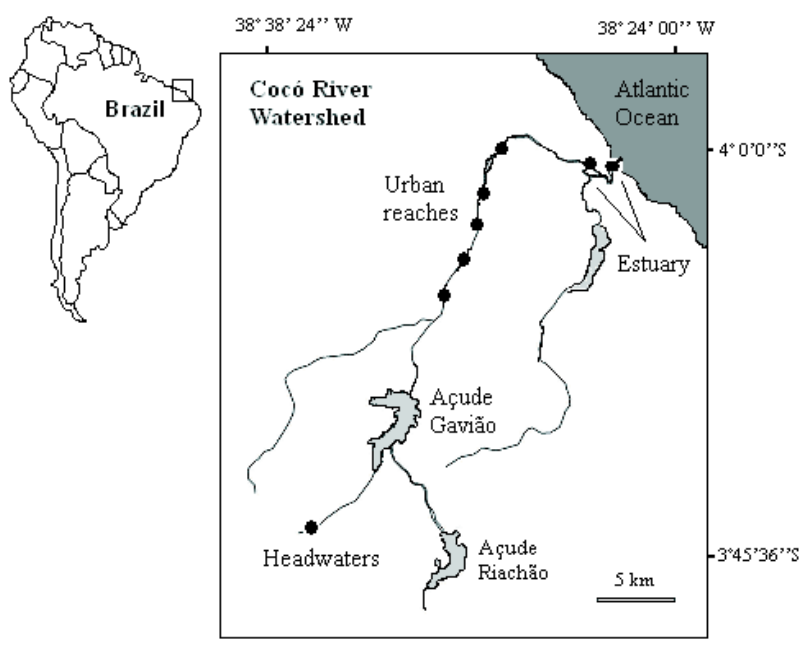

Figure 1 - Map of the Cocó River watershed showing the sampling sites across different river sections (headwater, urban and estuarine reaches). the Cocó River estuary is the extensive presence of mangrove forests and the dune fields that strongly influence the river route towards the ocean.

\section{Sampling procedure and chemical analysis}

Water samples were collected in July, September and December 2003 (dry season) and March, April and June 2004 (rainy season) from eight sampling sites, in order to include the headwater, urban and estuarine river sections (Fig. 1). At each sampling site, water samples were taken in $1 \mathrm{~L}$-polyethylene bottles and transported in an ice box to the laboratory. Dissolved oxygen (DO), electrical conductivity (EC), total dissolved solids (TDS), water temperature, and $\mathrm{pH}$ were measured using $\mathrm{YSI}$ 556 Multi Probe System. Salinity was measured in sampling sites under the influence of tides.

The samples were filtered though a $0.45 \mu \mathrm{m}$ acetate cellulose filter (Millipore HAWPO 4700) and the filtrate stored frozen until the completion of analysis. The concentrations of ammonia $\left(\mathrm{NH}_{4}^{+}\right)$, nitrate $\left(\mathrm{NO}_{3}{ }^{-}\right)$ and orthophosphate $\left(\mathrm{PO}_{4}{ }^{3-}\right)$ were measured spectrophotometrically in filtrate samples (APHA, 1998). Detection limits for $\mathrm{NH}_{4}{ }^{+} \mathrm{NO}_{3}{ }^{-}$and $\mathrm{PO}_{4}{ }^{3-}$ were $0.01 \mathrm{mg} /$ $\mathrm{L}, 0.05 \mathrm{mg} / \mathrm{L}$ and $0.01 \mathrm{mg} / \mathrm{L}$, respectively. The 5-days biochemical oxygen demand $\left(\mathrm{BOD}_{5}\right)$ was determined as the difference between initial and 5-day oxygen concentrations in bottles assayed by the Winkler method, after incubation at $20^{\circ} \mathrm{C}$. Turbidity was measured colorimetrically by light absorbance at 750 $\mathrm{mm}$ giving the value at NTU. Fecal coliform levels were determined by using the multiple-tube fermentation technique and reported in terms of the Most Probable Number (MPN) of organisms present per $100 \mathrm{~mL}$ (APHA, 1998).

\section{Hydrological data}

Measurements of Cocó River discharges, as well as for most rivers in Ceará state are either insufficient or not available at all. Thus, to assess the influence of dams on total discharge from the Cocó River basin to the estuary, we used the climate runoff model (Schreiber, 1904; Holland, 1978) to generate long-term mean discharges and to simulate the pre- and post-dam river conditions.

The climatic runoff model is based on the climatic water balance approach which assumes a balance between rainfall, evapotranspiration, and runoff. The runoff model has been shown to work well for a diverse number of fluvial/estuarine systems (Kjerfve et al., 1997; Restrepo and Kjerfve, 2000; Molisani et al., 2006a). The model requires long-term precipitation and temperature records ( 30-yr period) which were obtained from Fundação de Meteorologia do Estado do Ceará (FUNCEME), the Meteorology Foundation of Ceará State, who regularly measure rainfall and temperature 
at four meteorological stations in the drainage basin. The basin was divided in polygons (sub-basins) according to the five altitude classes (0-200, 200-400, 400-600, $600-800$ meters), similar to the procedure adopted by Kjerfve et al. (1997). Each polygon area was quantified using a digital GIS-based map. We calculated areaweighted estimates of precipitation and temperature for each polygon during the dry (July to December) and rainy seasons (January to June), from which the evapotranspiration, runoff ratio, and discharge were calculated separately. For polygons without temperature measurements, we corrected the temperature from adjacent meteorological stations adiabatically, i.e., by $-0.97^{\circ} \mathrm{C}$ per $100 \mathrm{~m}$ elevation increase (List, 1966).

Discharge $\left(Q_{R}, \mathrm{~m}^{3} / \mathrm{s}\right)$ from each sub-basin $(A$, $\left.\mathrm{m}^{2}\right)$ was computed as:

$$
Q=\iint r \times \frac{\Delta f}{r} \times d A
$$

(Kjerfve, 1990), where, $r$ is precipitation ( $\mathrm{mm} \mathrm{yr}^{-1}$ but converted in $\mathrm{m} \mathrm{s}^{-1}$ for use in equation 1), and the nondimensional quantity $\ddot{A} f / r$ is the non-dimensional runoff ratio, which expresses the fraction of rainfall converted into runoff. The runoff ratio was calculated from:

$$
\frac{\Delta f}{r}=e^{-E_{0} / r}
$$

Here $E_{0}$ is the potential evapotranspiration $\left(\mathrm{mm} \mathrm{yr}^{-1}\right)$, calculated by using the empirical dependence on air temperature ( $T$, degrees Kelvin):

$$
E_{0}=1.0 \times 10^{9} \times e^{-4620 / T}
$$

(Holland, 1978). By summing the contribution from each sub-basin, we estimated the discharge for the total drainage basin and simulated the pre-dam discharge from the watershed to the estuary. The post-dam discharge was estimated by calculating the runoff from the sub-basins below the most downstream dam across the watershed (Gavião reservoir) and summing this discharge with water release from this reservoir (COGERH, unpublished data). Water losses by evaporation, infiltration and withdrawal were not considered in the present estimate.

To simulate the pre- and post-dam discharges for the Cocó River, we first applied the runoff model (equation 1) to a gauged semi-arid river located in Ceará state and compared simulated and measured discharges to verify the applicability/accuracy of the model for semi- arid conditions. The gauged Jaguaribe River is located in the eastern part of the Ceará State and its features are also influenced by a semi-arid equatorial climate. This river had a gauge station at Iguatu that provided monthly discharge information from 1970 to 1992 (Duursma, 2002). To validate the model, simulated discharge for the Jaguaribe River was compared with the measured discharge for the same period.

\section{Statistical methods}

To validate the hydrological model, a simulated discharge for the gauged river was compared with the measurements through paired two-tailed $t$-Student test. In order to account for non-parametric distribution of measured water quality parameters in different river sections (headwater, urban and estuarine), a nonparametric Mann-Whitney $U$ test was conducted to obtain significant spatial differences.

\section{RESULTS}

\section{Hydrology}

To validate the hydrological model, simulated discharge for the Jaguaribe River was compared with the measured discharge. The mean discharge calculated from the model based on 22-yr normal temperature and rainfall data for this river section $(44 \pm$ $85 \mathrm{~m}^{3} / \mathrm{s}$ ) was not significantly different at the $95 \%$ confidence level $(P>0.05$, paired two-tailed $t$-Student test) from the mean measured discharge $\left(33 \pm 44 \mathrm{~m}^{3} /\right.$ $\mathrm{s})$. The agreement indicates that the model is robust and works well to establish order of magnitude for discharges in the watershed influenced by the semiarid tropical climate.

Long-term mean precipitation, temperature, potential evapotranspiration, and dimensionless runoff ratio as shown in Table 1 were used to estimate the pre-dam river discharge transported from catchments to the estuary for dry and rainy seasons. Before dam cascade construction, the Cocó River discharge transferred from the watershed to its estuary averaged $3.0 \mathrm{~m} / \mathrm{s}$ during the rainy season. In the dry season, discharge is absent, indicating the ephemeral condition of this watershed.

The same procedure was adopted to obtain river flow below the dam cascade and thus understand the post-dam discharge to the coast (Table 1). From the headwaters to the Gavião Reservoir, the river basin has $52 \mathrm{~km}^{2}$, representing $14 \%$ of the total catchment area. Based on our calculations, the river section downstream from the major dam until the estuary ( $86 \%$ of total basin area) has a long-term mean water discharge calculated at 3.5 and $<1 \mathrm{~m}^{3} / \mathrm{s}$ during the rainy and dry seasons, respectively. On average, the actual post-dam discharge 
Molisani et al.: Effects of water management on a semi-arid river system.

Table I - Summary of morphological and meteorological data used to characterize the mean pre- and post-dam discharge during rainy/dry season.

\begin{tabular}{lcccccc}
\hline \hline Cocó River basin & $\begin{array}{c}\text { Area } \\
\left(\mathrm{km}^{2}\right)\end{array}$ & $\begin{array}{c}\text { Te mperature } \\
\left({ }^{\circ} \mathrm{C}\right)\end{array}$ & $\begin{array}{c}\text { Rainfall } \\
(\mathrm{mm})\end{array}$ & $\begin{array}{c}E_{0} \\
(\mathrm{~mm})\end{array}$ & $\Delta f / r$ & $\begin{array}{c}\text { Discharge } \\
\left(\mathrm{m}^{3} / \mathrm{s}\right)\end{array}$ \\
\hline Pre-dam discharge & 360 & $26.2 / 25.2$ & $1086 / 223$ & $193 / 192$ & $0.17 / \sim 0^{\mathrm{a}}$ & $3.0 /<1$ \\
\hline $\begin{array}{l}\text { Post-dam discharge } \\
\begin{array}{l}\text { Below dams } \\
\text { Mean dam-released }\end{array}\end{array}$ & 308 & $26.4 / 25.3^{\mathrm{a}}$ & $1089 / 234^{\mathrm{a}}$ & $205 / 194^{\mathrm{a}}$ & $0.15 / \sim 0^{\mathrm{a}}$ & $3.0 /<1$ \\
$\begin{array}{l}\text { discharge } \\
\text { Discharge to the estuary }\end{array}$ & & & & & & $0.6 / 0.5$ \\
\hline \hline
\end{tabular}

a The values are expressed as area-weighted averages for each elevation polygon

${ }^{b}$ Estimated by summing the runoff from river basin below the Gavião Reservoir and its mean dam-released discharge.

to the estuary in rainy season is primarily determined by basin runoff $\left(3.0 \mathrm{~m}^{3} / \mathrm{s}\right)$ while dam-release discharges contribute to $0.6 \mathrm{~m}^{3} / \mathrm{s}$. The outflow from dam varies from 0.2 to $43 \mathrm{~m}^{3} / \mathrm{s}$ and occurs only $14 \%$ of monitoring time period (COGERH, unpublished data). In dry season, the natural runoff below the major dam does not exist because of ephemeral condition of this river while the dam-release discharge averaged $0.5 \mathrm{~m}^{3} / \mathrm{s}$ is responsible for the entirely land-sea water discharge during this season.

\section{Water quality}

Figures 2 - 6 show the spatial variability of water quality parameters from headwater to the estuary during the sampling period. Headwaters show significant lower values for TDS, conductivity, $\mathrm{BOD}, \mathrm{PO}_{4}{ }^{3-}, \mathrm{NH}_{4}{ }^{+}$, fecal coliform and higher $\mathrm{DO}$ levels than urban river section $(P<0.01)$. River conditions between headwater and urban reaches can not be statistically distinguished for temperature, turbidity, $\mathrm{pH}$, and nitrate during the sampling period $(P>0.05)$. The comparison between urban and estuarine river sections shows statistically lower concentrations of $\mathrm{NH}_{4}^{+}, \mathrm{PO}_{4}{ }^{3-}, \mathrm{NO}_{3}{ }^{-}$and higher values of $\mathrm{DO}$ and TDS occurring in the estuarine reach $(P<0.01)$. On the other hand, these areas can not be

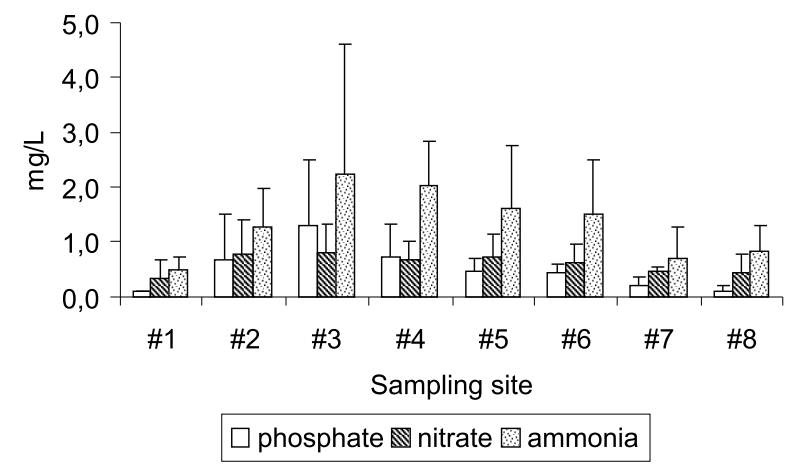

Figure 2 - Mean (bars denote S.D.) distribution of phosphate $\left(\mathrm{PO}_{4}{ }^{3-}\right.$ ), nitrate $\left(\mathrm{NO}_{3}^{-}\right)$and ammonia $\left(\mathrm{NH}_{4}^{+}\right)$in different river sections of the Cocó River during the sampling period (\#1 headwater; \#2 to \#6 urban; \# 7 and \# 8 estuary). differentiated for temperature, turbidity, conductivity, $\mathrm{pH}$, BOD, and fecal coliform $(P>0.05)$. Salinity varying from 24 to $31 \%$ was observed in estuarine sites during the sampling period.

All values were compared with the Brazilian Water Quality Guidelines (Conama Resolution 357, 2005) (Figure 2-6). Basically, headwaters lie in the Class 1 for freshwater aquatic environments, while urban river section lies in Class 4, mainly because of low levels of DO $(2,5 \mathrm{mg} / \mathrm{L})$ and high levels of fecal coliform (11,000 NMP/100 mL). The estuarine waters are characterized as Class 3 for seawater aquatic environments, in view of the low DO and high fecal coliform levels.

\section{DISCUSSION}

The Cocó River drains a typical semi-arid tropical watershed/estuarine system in the Northeast of Brazil where current demographic development is based on water resource management. About 30 dams are distributed across the watershed which suggests important alterations of land-sea river discharge. Despite the fact that there are numerous dams, these dams are located high in the catchment area and so do not

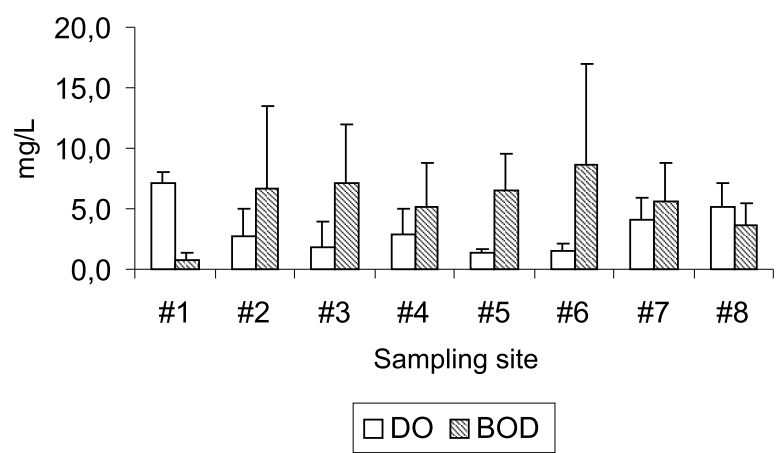

Figure 3 - Mean (bars denote S.D.) distribution of dissolved oxygen (DO) and 5-days biochemical oxygen demand (BOD) in different river sections of the Cocó River during the sampling period (\#1 headwater; \#2 to \#6 urban; \# 7 and \# 8 estuary). 


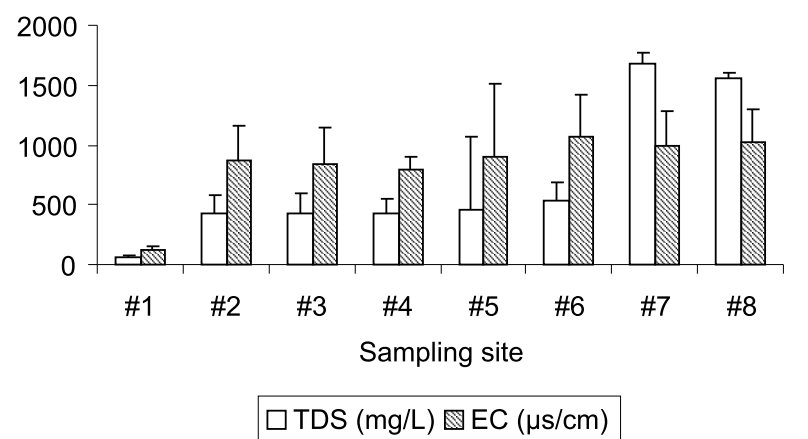

Figure 4 - Mean (bars denote S.D.) distribution of total dissolved solids (TDS) and electrical conductivity (EC) in different river sections of the Cocó River during the sampling period (\#1 headwater; \#2 to \#6 urban; \# 7 and \# 8 estuary).

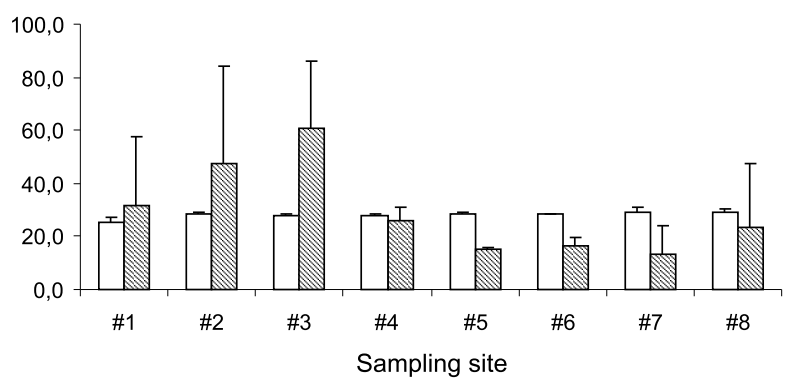

$\square$ Temperature $\left({ }^{\circ} \mathrm{C}\right)$ 圈 Turbidity (ntu)

Figure 5 - Mean (bars denote S.D.) distribution of temperature and turbidity in different river sections of the Cocó River watershed during the sampling period (\#1 headwater; \#2 to \#6 urban; \# 7 and \# 8 estuary).

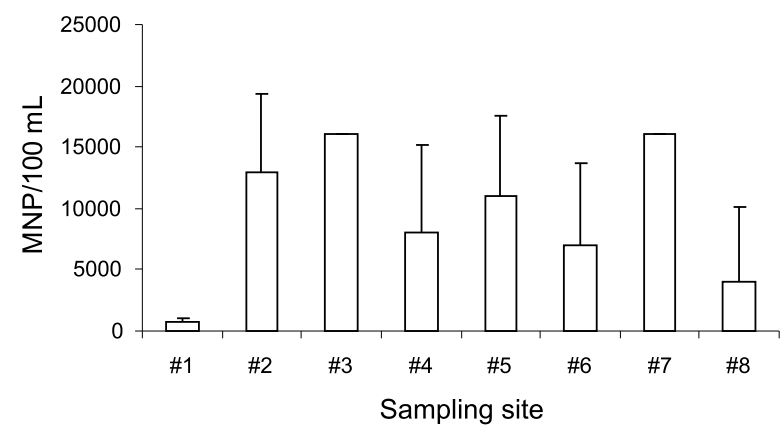

Figure 6 - Mean (bars denotes S.D.) distribution of fecal coliform in different river sections of the Cocó River during the sampling period (\#1 headwater; \#2 to \#6 urban; \# 7 and \# 8 estuary).

apparently have a large impact on total freshwater discharge to the coast as described by pre- and postdam discharge comparison (Table 2). In a neighboring watershed (Pacoti River) where most of the drainage basin is regulated by dams ( $85 \%)$, we can observe, using the same procedure, considerable reduction of post-dam discharges compared to pre-dam conditions (from 11 to $4 \mathrm{~m}^{3} / \mathrm{s}$ ). The reduction of the total water discharge to the coast has induced considerable disturbance in the estuary, such as siltation and bank formation which are consequently promoting the mangrove extension across the upstream estuary (Lacerda et al., in press).

Water management sustains social and economic development, however deficient waste treatment allows the return of consumed domestic water to the river channel as untreated sewage, impairing water quality of the Cocó River as exhibited by higher values of nutrients, fecal coliform, BOD, and lower DO levels in urban reaches. The importance of wastewater in determining the impairment of the Cocó River is exemplified by the inventory of nitrogen $(N)$ and phosphorous $(P)$ emission (SEMACE/ LABOMAR, 2006). This inventory shows that anthropogenic sources are responsible for $98 \%$ and $96 \%$ of total $\mathrm{N}(2,621 \mathrm{t} / \mathrm{yr})$ and $P(765 \mathrm{t} / \mathrm{yr})$ emission, respectively, while wastewaters account for $86 \%$ and $80 \%$ of such anthropogenic $\mathrm{N}$ and $\mathrm{P}$ emission.

Wastewater has induced severe pollution in urban and estuarine reaches and consequently both parameters are in disagreement with permissible levels from the Brazilian Water Quality Guidelines (Figure 3 and 6). The fecal coliform is being used as an indicator for sanitary standards (Crowther et al., 2002) and spatial trend of fecal coliform across the watershed also suggests direct disposal of sewage effluents into the river and/or failing septic systems. Additionally, organic matter from sewage effluents induces oxygen reduction in downstream reaches with depletion observed in some urban sites.

This scenario extends through estuarine reaches which for DO and fecal coliform levels cannot be statistically distinguished $(P>0.05)$ from the urban river section. High levels of fecal coliforms in the Cocó estuary were confirmed by Vieira and Façanha (1994) and these studies support the results of Silva et al. (2003) that found about $30 \%$ of oysters Crassostrea rhizophorae collected in the estuary improper for direct human consumption due to fecal coliform contamination. However, estuarine reaches show signs of water quality recovery compared to the urban river section, with significantly lower values of $\mathrm{NH}_{4}^{+}, \mathrm{NO}_{3}^{-}, \mathrm{PO}_{4}{ }_{4}^{--}$and higher DO $(P<0.01)$ (Figure 2 and 3). Data from Moreira (1994) also showed a similar pattern with improvement of water quality in the Cocó estuary compared to urban reaches under varying freshwater inflow and tidal regims.

Certain characteristics appear to be of primary importance in influencing estuarine response to pollution. Estuarine susceptibility to pollution is usually related to the dilution capacity of the water column which is equal to the estuarine volume, and to the flushing time, which is the time required for freshwater flow and tidal prism volume to replace the estuarine volume. Based on these parameters, an index to quantify the transport 
processes was developed using physical and hydrologic data (National Research Council, 2003).

To point out possible factors which improve the water quality of the Cocó estuary, we apply the index proposed by the National Research Council (2003). According to this analysis, the Cocó estuary has low dilution capacity based on its volume measured at $219,000 \mathrm{~m}^{3}$ (SEMACE/LABOMAR, 2006). Additionally, the relationship between estuarine volume and current (post-dam) seasonal freshwater discharge (Table 1) indicates fast flushing time of water in the estuary which varies, on average, from 17 hours (wet season) to 61 hours (dry season). By applying these data to the National Research Council (2003) classification, the Cocó Estuary, with relatively small volume and fast flushing time, has moderate susceptibility to nutrient input. Thus, we would expect the high degree of tidal flushing to tend to minimize human-related impacts within the Cocó Estuary and explain the marked improvement in water quality depending on the specific parameter.

\section{CONCLUSION}

Water resource management based on a dam cascade-diversion scheme suggests important first-order impacts on the Cocó River hydrology. As shown in the pre- and post-dam discharge comparison, the upstream location of dams apparently did not alter the total water discharge from watershed to the estuary. Asecond-order impact involves the impairment of water quality conditions of the river. It is related to the increasing water availability based on river management, social and economic development, and absence of proper waste treatment, which allows the returning of consumed domestic water to the river channel as untreated sewage. However, freshwater urban and estuarine reaches respond differently to wastewater pollution, probably based on the location of emission source and/or intrinsic processes (dilution and flushing) which reduce the susceptibility of estuarine reach to sewage pollution, but not in the urban river section.

\section{ACKNOWLEDGEMENT}

This work is supported by Superintendência Estadual do Meio Ambiente do Estado do Ceará (SEMACE). The author (MM Molisani) would like to thanks to Fundação Cearense de Apoio ao Desenvolvimento Cientifico e Tecnológico (FUNCAP) and National Research Council of Brazil (CNPq) to concession of DCR grant.

\section{REFERENCES}

Al-Kharabsheh, A.A. 1999. Influence of urbanization on water quality at Wadi Kufranja basin (Jordan). J. Arid Environs. 43, 79-89.

APHA, 1998. Standard methods for the examination of water and wastewater, American Public Health Association, $20^{\text {th }}$ ed. Washington, DC.

Batalla, R.J., Gómez, C.M. \& Kondolf, G.M. 2004. Reservoir-indiced hydrological changes in the Ebron River basin (NE Spain). J. Hydrol. 290, 117-136.

Campos, J.N.B. \& Studart, T.M.C. 2006. Water management and allocation in semi-arid areas of Brazil: Practices in Ceara State. Water Int. 31, 3136.

Chellappa, N. \& Costa, M.A.M. 2003. Dominant and co-existing species of Cyanobacteria from a Eutrophicated reservoir of Rio Grande do Norte State, Brazil. Acta Oecol. 24, S3-S10.

Cociasu, A.; Dorogan, L.; Humborg, C. \& Popa, L. 1996. Long-Term Ecological Changes in Romanian Coastal Waters of the Black Sea. Mar. Pollut. Bull. 32, 3238.

Conama Resolution 357.: 2005. Brazilian water quality guidelines, http://www.mma.gov.br/port/conama/ (Verified April 25, 2007).

Crowther, J.; Kay, D. \& Wyer, M.D. 2002. Faecalindicator concentrations in waters draining lowland pastoral catchments in the UK: relationships with land use and farming practices. Wat. Res. 36, 17251734.

Duursma, E. 2002. Rainfall, river flow and temperature profile trends: consequences for water resource, Heineken, Amsterdam, Netherlands [CD-ROM].

Gaiser, T.; Krol, M.S.; Frischkorn, H. \& Araujo, J.C. 2003. Global change and regional impacts: water availability and vulnerability of ecosystems and society in the semi-arid Northeast of Brazil', Berlin, Heidelberg, New York: Springer Verlag, 428 pp.

Gong, G.C.; Chang, J.; Chiang, K.P.; Hsiung, T.M.; Hung, C.C.; Duan, S.W. \& Codispoti, L.A., 2006. Reduction of primary production and changing of nutrient ratio in the East China Sea: Effect of the Three George Dam? Geophys. Res. Lett. 33, 1-4.

Güntner, A.; Krol, M.S.; Araújo, J.C. \& Bronstert, A. 2004. Simple water balance modelling of surface reservoir systems in a large data-scarce semi-arid region. Hydrological Sciences-Journal-des Sciences Hydrologiques 49, 901-918.

Harashima, A.; Kimoto, T.; Wakabayashi, T. \& Toshiyasu, T. 2006. Verification of the sílica deficiency hypothesis base don biogeochemical trends in the aquatic continuum of Lake Biwa-Yodo river -Seto inland Sea, Japan. Ambio 35, 36-42. 
Holland, H.D. 1978. The chemistry of the atmosphere and oceans, Wiley, New York, Washington, 351 pp.

Kjerfve, B. 1990. Unesco/United Nations Development Program Regional Mangrove Project, RAS 79/002 and RAS/86/120, 79 pp.

Kjerfve, B.; Ribeiro, C.H.; Dias, G.T. \& Fillippo, A.M. 1997. Oceanographic characteristics of an impacted coastal bay: Baía de Guanabara, Rio de Janeiro, Brazil. Cont. Shelf Res. 17, 1609-1643.

Lacerda, L.D.; Teles, M.O. \& Molisani, M.M. Changes in mangrove extension in the Pacoti River, Ceará State Northeastern Brazil due to regional environmental changes between 1958 and 2004. Biota Neotrop. (in press).

List, R.J. 1966. Smithsonian Meteorological Tables, 6th ed., Smithsonian Institution, Washington, USA, 527 pp.

Maingi, J.K. \& Marsh, S.E. 2002. Quantifying hydrologic impacts following dam construction along the Tana River, Kenya. J. Arid Environs. 50, 53-79.

Marins, R.V.; Freire, G.S.S.; Maia, L.P.; Lima, J.P.R. \& Lacerda, L.D. 2002. Impacts of land-based activities on the Ceará coats, north-eastern Brazil, in L.D. Lacerda, H.H. Kremer, B. Kjerfve, W. Salomons, J.I. Marshall Crossland and C.J. Crossland (eds.), South American Basins: LOICZ Global Change Assessment and Synthesis of River Catchment Coastal Sea Interaction and Human Dimensions. LOICZ Reports \& Studies.

Molisani, M.M.; Kjerfve, B.; Silva, A.P. \& Lacerda, L.D. 2006a. Water discharge and sediment load to Sepetiba Bay from an anthropogenically-altered drainage basin, SE Brazil. J. Hydrol. 331, 425-433.

Molisani, M.M.; Moreira, M.O.P.; Conceição, R.N. \& Maia, L.P. 2006b. Estuários do estado do Ceará: uma avaliação das condições ambientais. Revista de Ciência e Tecnologia FUNCAP 8, 6-7.

Molisani, M.M.; Kjerfve, B.; Barreto, R. \& Lacerda, L.D. 2007. Land-sea mercury transport through a modified watershed, SE Brazil. Wat. Res. 41, 19291938.
Moreira, M.O.P. 1994. Produção do fitoplâncton em um ecossistema estuarino tropical (estuario do rio Cocó, Fortaleza, Ceara), MSc Thesis, Universidade Federal de Pernambuco, Recife, Brazil, 338 pp.

National Research Council 2003. Clean Coastal Waters: Understanding and reducing the effects of nutrient pollution, Natl. Academy Press, Washington, D.C. $405 \mathrm{pp}$.

Restrepo, R.D. \& Kjerfve, B. 2000. Water discharge and sediment load from Western slopes of the Colombian Andes with focus on Rio San Juan. J. Geol. 108, 17-33.

Schreiber, P. 1904. Uberdie Beziehungen zwischen dem Niederschlag und der Wasserfhrung der Flusse in Mittleeuropa. Meteorologische Zeitungen 21, 44152.

SEMACE/ LABOMAR 2006. Zoneamento Ecológico e Econômico da Zona Costeira do Estado do Ceará, $147 p$.

Silva, A.I.M.; Vieira, R.H.S.F.; Menezes, F.G.R.; Filho, A.A.F.; Torres, R.C.O. \& Sant'Anna, E.S. 2003. Bacteria of fecal coliform origin in mangrove oyster (Cassostrea Rhizophorae) in the Cocó River Estuary, Ceará State, Brazil. Braz. J. Microbiol. 34, 126-130.

Singer, M.B. 2007. The influence of major dams on hydrology through the drainage network of the Sacramento River basin, Califórnia. River Res. Applic. 23, 55-72.

Vieira, R.H.S.F. \& Façanha, S.H.F. 1994 Parâmetros físico-químicos e pesquisa de coliformes totais e fecais e Vibrio parahaemolyticus nas águas do Rio Cocó, Fortaleza, Ceará. Ciên. Agron. 25, 24-31.

Vieira, R. H.S.; Rocha, C.A.S.; Menezes, F.G.R.; Aragão, J.S.; Rodrigues, D.P.; Theophilo, G.N.D. \& Reis, E.M. 2002. Poluição da água do mar e da areia em três praias de Fortaleza, Ceará, Brasil. Arq. Ciên. Mar. 35, 113-118.

WCD 2000. Dams and development - a new framework for decision-making. World Commission of Dams. Earthscan Publications Ltd, London and Sterling VA, USA. 